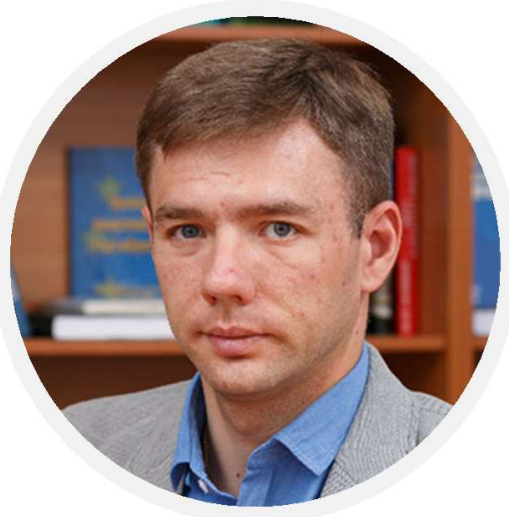

\title{
Віталій Гацелюк
}

Старший науковий співробітник відділу проблем кримінального права, кримінології та судоустрою Інституту держави і права імені В.М. Корецького НАН України, к.ю.н., заслужений юрист України, Київ, Україна vitalii.gatseliuk@osce.org ORCID ID: https://orcid.org/0000-0002-6958-2067

\section{КОНСТИТУЦІЙНІ МЕЖІ НАЦІОНАЛЬНОЇ СИСТЕМИ ЗАБЕЗПЕЧЕННЯ ПРАВОПОРЯДКУ}

\section{THE CONSTITUTIONAL FRAMEWORK FOR NATIONAL SYSTEM OF MANAGING PUBLIC ORDER}

\section{Vitalii Hatseliuk}

Senior Research Fellow, Department of Criminal Law, Criminology and Judiciary, V. Koretskyy Institute of State and Law, National Academy of Sciences of Ukraine, Ph.D., Honored Lawyer of Ukraine Kyiv, Ukraine

\begin{abstract}
The article explores the status and role in the hierarchy and structure of state power of bodies involved in public order, as their powers to restrict human rights and freedoms and the practice of exercising these powers can both promote and significantly impede the development of a democratic state governed by the rule of law.

It is emphasized that the prosecutor's office is important but by no means the only, element of the system of bodies with statutory powers to restrict human rights to ensure law and order. The criteria for referring to the latter should be considered the authority to stop illegal behavior (in particular, through the use of force, special means, or firearms), protection of public order, the fight against crime (operational and investigative activities, pre-trial investigation). Traditionally, such bodies were called law enforcement, including those at the level of a special law, according to which law enforcement agencies include the prosecutor's office, the National Police, the Security Service, the Military Law Enforcement Service in the Armed Forces of Ukraine, the National Anti-Corruption Bureau of Ukraine, state border guards, and tax authorities, institutions of execution of punishments, pre-trial detention centers, state financial control authorities, fish and forest protection agencies, other bodies which carry out law enforcement functions.

Given the position of the Constitutional Court of Ukraine, a system of criteria has been formulated, according to which the Court determines a state authority with executive powers as constitutional: functional purpose; a sphere of activity; powers; non/subordination to the Government; non/membership in the system of executive bodies.

It is concluded that the law enforcement system is a set of norms, principles, practices of their application, and the subjects who exercise the relevant powers to ensure strict compliance with the rule of law and human
\end{abstract}


rights in a democratic society. The provisions of the Constitution concerning law enforcement agencies, the prosecutor's office, and public order agencies contextually establish the general structural principles of functioning of the national law enforcement system. The prosecutor's office cannot be classified as a public order/law enforcement agency, however, given its functions, it is an important part of the law enforcement system. The discourse of assigning the prosecutor's office to one of the "branches" of power (structural) in the practical sense necessitates the adaptation of stereotypes about the essence of the separation of powers to the complex status of the prosecutor's office. Instead, the functional approach (through the definition of the main characteristics of the functions performed by the prosecutor's office) makes it possible to determine the appropriate status and take it into account when determining the system of checks and balances. The Constitution provides clear grounds for differentiating between law enforcement and public order agencies. Any system of law enforcement and public order agencies must comply with the principles of the constitutional order, guarantee the protection of human rights and freedoms and prevent the usurpation of power, by the letter or spirit of the Basic Law.

Keywords: law enforcement agencies, prosecutor's office, separation of power, system of checks and balances.

Анотація | вноваження щодо обмеження прав та свобод людини та громадянина і практика застосування цих повноважень можуть як сприяти, так і суттєво шкодити розвитку демократичної правової держави.

Підкреслюється, що прокуратура є важливим, але далеко не єдиним елементом системи органів, які мають визначені законодавством повноваження обмежувати права людини задля забезпечення правопорядку. Критеріями віднесення до останніх слід вважати повноваження із припинення протиправної поведінки (зокрема шляхом застосування сили, спеціальних засобів чи вогнепальної зброї), охорони громадського поряду, боротьби зі злочинністю (оперативно-розшукова діяльність, досудове розслідування). Традиційно такі органи іменувалися правоохоронними, в тому числі на рівні спеціального закону, відповідно до якого правоохоронні органи - це органи прокуратури, Національної поліції, служби безпеки, Військової служби правопорядку у Збройних Силах України, Національне антикорупційне бюро України, органи охорони державного кордону, органи доходів і зборів, органи і установи виконання покарань, слідчі ізолятори, органи державного фінансового контролю, рибоохорони, державної лісової охорони, інші органи, які здійснюють правозастосовні або правоохоронні функції.

3 огляду на позиції Конституційного Суду України, сформульовано систему критеріїв, за якими Судом визначається не/конституційність державного органу з виконавчими повноваженнями: функціональне призначення; сфера діяльності; повноваження; непідпорядкування Уряду; неналежність до системи органів виконавчої влади.

Зроблено висновок про те, що система забезпечення правопорядку є сукупністю норм, принципів, практики їх застосування та суб’єктів, що реалізують відповідні повноваження з метою гарантування неухильного дотримання приписів права та забезпечення прав людини у демократичному суспільстві. Приписи Конституції стосовно правоохоронних органів, прокуратури та органів правопорядку контекстуально встановлюють загальні структурні засади функціонування національної системи органів правопорядку. Прокуратура не може бути віднесена до органів правопорядку, але з огляду на здійснювані нею функції є важливою складової системи забезпечення правопорядку. Дискурс віднесення прокуратури до однієї з «гілок» влади (структурний) в практичному сенсі спричинює необхідність адаптації стереотипів щодо сутності розподілу влади до складного за своїм змістом статусу прокуратури. Натомість функціональний підхід (через визначення основних характеристик функцій, які виконуються прокуратурою) дає можливість визначити відповідний статус і враховувати його при визначенні системи стримувань та противаг. Конституція дає чіткі підстави для проведення диференціації органів правопорядку та правоохоронних органів. Будь-яка система органів правопорядку та правоохоронних органів має відповідати засадам конституційного ладу, гарантувати захист прав та свобод людини і запобігати узурпації влади, відповідно до букви або духу Основного закону.

Ключові слова: органи правопорядку, прокуратура, розподіл влади, система стримувань та противаг. 
У Рішенні від 25 січня 2012 року № 3-рп/20121 Конституційний Суд України, процитувавши частину першу статті 6 Конституції України, зазначив, що державна влада в Україні здійснюється на засадах її поділу на законодавчу, виконавчу та судову. Частина друга цієї ж статті встановлює, що органи законодавчої, виконавчої та судової влади здійснюють свої повноваження у встановлених цією Конституцією межах і відповідно до законів України.

Розподіл «гілок» влади не $\epsilon$ річчю в собі і несе цілком чітко окреслений функціонал, що полягає у побудові стримувань та противаг між ними в демократичному суспільстві², що має забезпечити сталий розвиток суспільства і держави на засадах демократії, верховенства права та дотримання прав людини. Саме з такої перспективи слід розглядати цей принцип, адже без розуміння його функції і мети він втрачав би сенс, а суто механічне розмежування влади на законодавчу, виконавчу і судову могло б вести як до дисфункції системи державного управління, так і до узурпації та зловживання владою в державі. Водночас, як зазначає М. Косюта, абсолютизація відокремленості й незалежності окремих гілок влади і, відповідно, складових державного механізму на практиці може призвести до його нежиттєздатності. Так само шкідливим є розуміння системи стримувань i противаг у відносинах між владними структурами як постійного протистояння між ними, коли їхні основні зусилля витрачаються на врегулювання конфліктів, а не на вирішення конкретних проблем державного будівництва 3 .

При цьому, важливе значення мають два елементи такого розподілу: 1) встановлення параметрів такого розподілу у Конституції та законах 4 ; 2) дотримання відповідними органами у своїй діяльності положень, визначених у законодавстві з метою забезпечення поділу влади 5 .

У цьому контексті важливе значення має статус та роль в ієрархії та структурі державної влади органів, що беруть участь у забезпеченні правопорядку, оскільки їх повноваження щодо обмеження прав та свобод людини та громадянина і практика застосування цих повноважень можуть як сприяти, так і суттєво зашкоджувати розвитку демократичної правової держави.

Прикладом цього є остання масштабна криза конституційного ладу 2013-2014 років в Україні, поштовхом до якої стали явно непропорційні дії органів МВС на Майдані Незалежності у Києві з припинення мирного зібрання у ніч з 29 на 30 листопада 2013 року.

Жорстоке протистояння учасників масових зібрань та підрозділів охорони громадського порядку і внутрішніх військ, яке переросло по суті у перегляд суспільного договору, ставить питання про пошук у Основному законі орієнтирів, за якими має будуватися той елемент апарату держави, який відповідає за фундаментальну функцію держави щодо забезпечення правопорядку

\footnotetext{
1 Рішення Конституційного Суду України у справі за конституційним поданням правління Пенсійного фонду України щодо офіційного тлумачення положень статті 1, частин першої, другої, третьої статті 95, частини другої статті 96, пунктів 2, 3, 6 статті 116, частини другої статті 124, частини першої статті 129 Конституції України, пункту 5 частини першої статті 4 Бюджетного кодексу України, пункту 2 частини першої статті 9 Кодексу адміністративного судочинства України в системному зв'язку з окремими положеннями Конституції України від 25 січня 2012 року № 3-pп/2012. URL: https://zakon.rada.gov.ua/laws/show/v003p710-12\#Text (18.10.2021).

2 «За змістом принципу поділу державної влади в Україні, визначеного у частині першій статті 6 Конституції України, "державна влада здійснюється на засадах її поділу на законодавчу, виконавчу та судову", які урівноважують одна одну системою стримувань і противаг».

Див.: Рішення Конституційного Суду України у справі щодо підвідомчості актів про призначення або звільнення посадових осіб від 7 травня 2002 року № 8-рп/2002. URL: https://zakon.rada.gov.ua/laws/show/v008p710-02\#Text (18.10.2021).

3 Косюта М. Роль і місце прокуратури України в системі поділу влади. Науковий часопис Національної академії прокуратури України. 2017. № 4(16). С. 101-113.

4 Згідно з юридичною позицією Конституційного Суду України, викладеною в Рішенні від 24 червня 1999 року № 6-рп/99 у справі про фінансування судів, метою функціонального поділу державної влади на законодавчу, виконавчу та судову $є$ розмежування повноважень між різними органами державної влади та недопущення привласнення повноти державної влади однією з гілок влади. URL: https://zakon.rada.gov.ua/laws/show/v006p710-99\#Text (18.10.2021).

5 Так, у Рішенні від 1 квітня 2008 року № 4-рп/2008 Конституційний Суд України наголосив, що неухильне додержання органами законодавчої, виконавчої та судової влади Конституції та законів України забезпечує реалізацію принципу поділу влади і є запорукою їх єдності, важливою передумовою стабільності, підтримання громадського миру і злагоди в державі. URL: https://zakon.rada.gov.ua/laws/show/v004p710-08\#Text (18.10.2021).
} 
і покликаний протидіяти правопорушенням, в том числі злочинам, і таким чином сприяти утвердженню прав людини та верховенства права.

Інакше кажучи, яким чином мають бути вбудовані органи забезпечення правопорядку у систему стримувань і противаг, аби належно збалансовувати визначений Конституцією поділ влади? Пошук відповіді на це питання і є метою даної статті. При цьому, «органи забезпечення правопорядку» вживаються нами у значенні публічно-інституціональної підсистеми забезпечення правопорядку в розумінні А. Крусян 6 .

Питання статусу та місця в системі розподілу влади прокуратури та правоохоронних органів, а також поняття правопорядку як правового феномену досліджувалися такими вченими, як В. Бринцев, Л. Грицаєнко, Ю. Грошевий, В. Долежан, М. Козюбра, О. Костенко, М. Костицький, М. Косюта, Н. Крестовська, А. Крижанівський, І.Марочкін, А. Лапкін, В. Лемак, Л. Луць, Н. Пархоменко, 0. Петришин, С. Погребняк, Ю. Полянський, С. Прилуцький, С. Різник, О. Толочко, В. Сухонос, Ю. Шемшученко, 0.0. Шмельов та інші.

Важливість цього питання була визнана розробниками чинної Конституції України, які в пункті 9 Розділу XV «Перехідні положення» окремо передбачили, що прокуратура продовжує виконувати відповідно до чинних законів функцію нагляду за додержанням і застосуванням законів та функцію попереднього слідства - до введення в дію законів, що регулюють діяльність державних органів щодо контролю за додержанням законів, та до сформування системи досудового слідства і введення в дію законів, що регулюють її функціонування.

Це застереження було викликано, зокрема, тим, що роком раніше, у 1995 році при вступі до Ради Європи України взяла на себе зобов'язання такого змісту: роль та функції Генеральної прокуратури будуть змінені (особливо щодо здійснення загального контролю за додержанням законності) шляхом перетворення цього інституту в орган, який відповідатиме стандартам Ради Європи.

При цьому у висновку Парламентської Асамблеї Ради Європи щодо заявки України на вступ до Ради Європи № 190 зміна функцій прокуратури була на рівні із такими кроками, як прийняття нової Конституції, низки нових кодексів та рамкових документів про правову та судову реформу та правову політику у сфері захисту прав людини, визначена критерієм того, чи Україна здатна і бажає виконувати обов'язки члена Ради Європи, визначені у ст. 3, а саме визнати принципи верховенства права та здійснення прав і основних свобод людини всіма особами, що знаходяться під його юрисдикцією, і ефективно співробітничати в досягненні мети Ради.

Таким чином, навіть не/належне позиціонування та/або функціонування одного із органів правопорядку здатне бути каменем спотикання на шляху до демократичної правової держави, адже ніколи прокуратура, так само, як і інші споріднені за спрямуванням установи, не були повністю поза межами політичних процесів. Це підтвердилося і практикою реалізації п. 9 Перехідних положень Конституції. Так званий загальний нагляд було скасовано лише у 2014 році при ухваленні нового закону про прокуратуру7 , а позбавлення функції досудового розслідування відбулося у листопаді 2018 року із початком функціонування Державного бюро розслідувань.

Втім, прокуратура $є$ важливим, але далеко не єдиним елементом системи органів, які мають визначені законодавством повноваження обмежувати права людини задля утвердження тих самих прав людини та забезпечення правопорядку. Критеріями віднесення до останніх слід вважати повноваження із припинення протиправної поведінки (зокрема шляхом застосування сили, спеціальних засобів чи вогнепальної зброї), охорони громадського поряду, боротьби зі злочинністю (оперативно-розшукова діяльність, досудове розслідування).

\footnotetext{
${ }^{6}$ Крусян А. Конституційний правопорядок у системі сучасного українського конституціоналізму. Юридичний вісник. 2009. № 1. С. 16 - 21.

7 Закон України «Про прокуратуру» від 14 жовтня 2014 року №1697-VII. URL: https://zakon.rada.gov.ua/laws/show/169718\#Text (18.10.2021).
} 
Традиційно такі органи іменувалися правоохоронними, в тому числі на рівні закону9, відповідно до якого «у цьому законі» правоохоронні органи - це органи прокуратури, Національної поліції, служби безпеки, Військової служби правопорядку у Збройних Силах України, Національне антикорупційне бюро України, органи охорони державного кордону, органи доходів і зборів, органи і установи виконання покарань, слідчі ізолятори, органи державного фінансового контролю, рибоохорони, державної лісової охорони, інші органи, які здійснюють правозастосовні або правоохоронні функції.

Однак цей перелік не $є$ per se достатнім для визначення правоохоронного органу, адже на думку Конституційного Суду, «згідно з абзацом другим пункту 1 статті 2 Закону захисту підлягають працівники суду і правоохоронних органів, зазначених в абзаці першому цього пункту, а також співробітники кадрового складу розвідувальних органів України, працівники Антимонопольного комітету України та уповноважені особи Національної комісії з цінних паперів та фондового ринку, які беруть безпосередню участь, зокрема, у виконанні вироків, рішень, ухвал і постанов судів, постанов органів дізнання і попереднього слідства та прокурорів (підпункт "д"). Напрями діяльності, вказані у цьому абзаці, не можна вважати додатковими підставами для віднесення органів, що провадять таку діяльність, до правоохоронних. Визначивши ці напрями, законодавець розширив коло осіб, які поряд із працівниками суду і правоохоронних органів підлягають державному захисту відповідно до Закону, що $є$ цілком виправданим з огляду на його завдання»10.

Відсутній єдиний підхід до цього правового феномену і в науці. Так, В. Тацій зазначав, що поняття «правоохоронні органи» $є$ одним із найбільш невизначених в українському правознавстві, внутрішньо суперечливим за змістом і надмірним за обсягом... Як результат виникає конкурентність термінів - «правоохоронні органи», «правозахисні органи», «органи кримінальної юстиції». До системи правоохоронних органів відносять різні за своїм статусом та функціональним призначенням органи, що унеможливлює визначення їх системи... Виходом із цієї термінологічної плутанини може бути збереження поняття «правоохоронні органи» лише як узагальнюючого наукового поняття і здійснення поділу цієї системи органів залежно від їх конкретних функцій та призначення в механізмі охорони права. У зв'язку з цим пропонується виокремити: 1) органи охорони правопорядку; 2) контрольні (юрисдикційні) органи виконавчої влади; 3) органи охорони Конституції та державного контролю11.

Конституція України лише один раз згадує правоохоронні органи - у статті 17, яка визначає, що забезпечення державної безпеки і захист державного кордону України покладаються на відповідні військові формування та правоохоронні органи держави, організація і порядок діяльності яких визначаються законом.

Це - єдине місце, у якому згадуються правоохоронні органи, проте інші статті Основного закону певною мірою регламентують функціональні межі таких утворень.

\footnotetext{
8 Зокрема, незадовільний стан реформування саме правоохоронних органів було підкреслено, наприклад, авторами проєкту Постанови Верховної Ради України «Про стан реформування правоохоронних органів України та законодавче забезпечення їх діяльності»: «Останнім часом простежується тенденція до політизації правоохоронних органів, що $\epsilon$ небезпечним явищем для забезпечення охорони правопорядку в державі. Це свідчить про відхід керівництва цих органів від визначених Конституцією та законами України принципів їх функціонування у правовій державі». URL: http://w1.c1.rada.gov.ua/pls/zweb2/webproc4_1?pf3511=18865 (18.10.2021).

9 Закон України «Про державний захист працівників суду і правоохоронних органів» від 23 грудня 1993 року №3781-ХІІ. URL: https://zakon.rada.gov.ua/laws/show/3781-12\#Text (18.10.2021).

10 Рішення Конституційного Суду України у справі за конституційним зверненням громадянина Кузьменка Віталія Борисовича щодо офіційного тлумачення положення частини третьої статті 364 Кримінального кодексу України (справа щодо застосування кваліфікуючої ознаки "працівник правоохоронного органу" до працівника державної виконавчої служби) від 18 квітня 2012 року №10-рп/2012. URL: https://zakon.rada.gov.ua/laws/show/v010p710-12\#Text (18.10.2021). 11 Тацій В. Поняття та система правоохоронних органів: у контексті системних змін до Конституції України. Вісник Академії правових наук України. 2012. № 4. С. 3-17.
} 
Зокрема, стаття $131^{1}$ Конституції закріплює, що в Україні діє прокуратура, яка здійснює серед іншого організацію і процесуальне керівництво досудовим розслідуванням, вирішення відповідно до закону інших питань під час кримінального провадження, нагляд за негласними та іншими слідчими і розшуковими діями органів правопорядку12.

3 цього випливає, що одними із функцій органів правопорядку Конституція визначає слідчі та розшукові дії (як гласні, так і негласні).

Загалом, на думку С. Єсімова, діяльність органів публічної влади щодо забезпечення правопорядку містить низку напрямів, які сприяють встановленню конституційного правопорядку:

- забезпечення конституційного оформлення чинного законодавства (усунення законодавчих прогалин, забезпечення ієрархічності правових актів, якісного законодавчого регулювання при збереженні цілісної правової стабільності);

- забезпечення верховенства права та Конституції за допомогою забезпечення єдності нормативно-правового простору;

- належний нагляд і контроль за реалізацією правових приписів;

- протидія правопорушенням тощо ${ }^{13}$.

3 огляду на положення статті 92 Конституції про те, що виключно законами визначаються організація і діяльність прокуратури, ... органів досудового розслідування, $є$ підстави зробити висновок, що органи досудового розслідування охоплюються поняттям органів правопорядку, до складу яких можуть входити також ті, що проводять оперативно-розшукову діяльність.

Водночас прокуратура згадується окремо, і не лише у статті 92. Зокрема, підтримання публічного обвинувачення в суді прокурором є однією з основних засад судочинства (стаття 129); piшення стосовно порушення суддею чи прокурором вимог щодо несумісності ухвалює, а скарги на рішення відповідного органу про притягнення до дисциплінарної відповідальності судді чи прокурора розглядає Вища рада правосуддя. Крім того, відповідно до закону органи та установи для забезпечення добору прокурорів, їх професійної підготовки, оцінювання, розгляду справ щодо їх дисциплінарної відповідальності утворюються в системі правосуддя (стаття 131).

3 огляду на це в літературі висловлюється позиція, відповідно до якої прокуратура (як мінімум з 2016 року внаслідок внесення змін до Конституції України ${ }^{14}$ ) входить до судової влади. При цьому, використовуються різні терміни (судова влада, система правосуддя), в тому числі як синоніми ${ }^{15}$.

Щодо місця прокуратури у системі розподілу влади дискусії точаться доволі давно і позиції дослідників часом кардинально відрізняються від віднесення її до тієї чи іншої влади (причому, лунали думки щодо будь-якої із «класичної» тріади) до обгрунтування її статусу як самостійного/спеціального державного інституту поза межами зазначеної тріади ${ }^{16}$, «відокремленої і самостійної системи органів із широкими повноваженнями елемент механізму стримувань і противаг у системі поділу влади»17, «самостійний інститут державної влади, який реалізує покладені на нього Конституцією та законами України функції у взаємодії з іншими органами державної влади;

\footnotetext{
12 Цей набір функції було оцінено Венеційською комісією як такий, що відповідає Європейським стандартам та їі рекомендаціям. Див.: Opinion on the Amendments to the Constitution of Ukraine regarding the Judiciary as proposed by the Working Group of the Constitutional Commission in July 2015 endorsed by the Venice Commission at its 104th Plenary Session (Venice, 23-24 October 2015) URL: https://www.venice.coe.int/webforms/documents/?pdf=CDL-AD(2015)026-e (18.10.2021).

13 Єсімов С.С. Реалізація конституційного оформлення правопорядку в умовах наявності конституційних ризиків. Соціально-правові студії. 2019. Випуск 3. С. 52-57.

14 Закон України «Про внесення змін до Конституції України (щодо правосуддя)» від 2 червня 2016 року №1401-VIII. URL: https://zakon.rada.gov.ua/laws/show/1401-19\#n2 (18.10.2021).

15 «...долучення прокуратури до судової влади (або до системи правосуддя, оскільки ці поняття

можуть розглядатися і як синоніми)». Косюта М. Роль і місце прокуратури України в системі поділу влади. Науковий часопис Національної академії прокуратури України. 2017. № 4(16). С. 101-113.

16 Конституційне право України: підруч. / за ред. В.Ф. Погорілка. - Київ: Наукова думка. 1999. С. 596.

17 Лапкін А. Прокуратура в системі судової влади. Право України. 2015. № 9. С. 164-171.
} 
самостійна одиниця в державному механізмі» 18 , «система органів, які забезпечують конституційну законність у діяльності владних інституцій, зокрема тих, що здійснюють оперативно-розшукову діяльність, досудове розслідування, виконання судових рішень тощо»19.

При цьому, термін «правопорядок» згадується у статті 119 Конституції, відповідно до якої місцеві державні адміністрації на відповідній території забезпечують... законність і правопорядок; додержання прав і свобод громадян, а забезпечення правопорядку визначається у науці як один 3 основних і найважливіших напрямів діяльності держави, пов'язаної із захистом, гарантуванням основних прав і свобод людини і громадянина 20.

3 огляду на зазначене вище, зокрема положення статті $131^{1}$ Конституції, навряд чи можна погодитися із думкою про те, що нині в Україні відбувається процес перетворення прокуратури на систему органів правопорядку відповідно до європейських стандартів 21. «Суміжним» відносно судоустрою та правосуддя правовим інститутом прокуратуру названо у відповідній Стратегії національного рівня 22.

В контексті балансу стримувань та противаг в системі розподілу влади основними елементами в контексті визначення координат системи органів правопорядку (в тому числі стосовно Генерального прокурора, оскільки ця фігура через конституційні повноваження прокуратури безпосередньо впливає на контроль і нагляд за діяльністю органів правопорядку), є наступні (статті 85, 106):

- Надання парламентом згоди на призначення на посаду та звільнення з посади Президентом України Генерального прокурора; висловлення недовіри Генеральному прокуророві, що має наслідком його відставку з посади.

- Призначення парламентом на посаду та звільнення з посади за поданням Президента України Голови Служби безпеки України.

- Затвердження парламентом загальної структури, чисельності, визначення функцій Служби безпеки України, ..., інших утворених відповідно до законів України військових формувань, а також Міністерства внутрішніх справ України.

Підсумовуючи загальні застереження, наведені вище, зауважимо, що Конституція не дає вичерпних текстуальних відповідей на те, який статус та місце в системі розподілу влад мають органи правопорядку, до яких станом на червень 2021 року варто віднести такі інституції, які задіяні в охороні державного кордону; забезпеченні громадського порядку та боротьби з тероризмом, організованою злочинністю; є суб'єктами оперативно-розшукової діяльності або містять у своєму складі органи досудового розслідування, проте це не означає, що Основний Закон не лімітує цей статус контекстуально.

18 Шапошник А.С., Шлапко Т.В. Визначення місця прокуратури в системі органів державної влади. Правова позиція. 2020. №3. C. 71-75.

19 Тацій В. Поняття та система правоохоронних органів: у контексті системних змін до Конституції України. Вісник Академії правових наук України. 2012. № 4. С. 3-17.

20 «У чинних нормативних правових актах категорія «правопорядок» може мати абсолютно різне смислове навантаження; неоднозначно може бути розтлумачено і її обсяг, і зміст. До прикладу, деколи законодавець фактично зводить забезпечення правопорядку або до боротьби зі злочинністю, або до охорони громадського порядку, або до запобігання правопорушенням, тобто зводить його виключно до правоохоронної діяльності держави та охоронної функції права». Подорожна Т.С. Правовий порядок: теоретико-методологічні засади конституціоналізації. Дис... доктора юрид наук. С. 48.

21 Косюта М. Роль і місце прокуратури України в системі поділу влади. Науковий часопис Національної академії прокуратури України. 2017. № 4(16). С. 101-113.

22 Указ Президента України від 20 травня 2015 року №276/2015 «Про Стратегію реформування судоустрою, судочинства та суміжних правових інститутів на 2015-2020 роки». URL: https://zakon.rada.gov.ua/laws/show/276/2015\#Text (18.10/2021). 
До речі, Конституційний Суд України ототожнює правоохоронні органи та органи правопорядку, принаймні у випадку із НАБУ23, що навряд чи можна вважати бездоганною позицією 3 огляду на норми Основного закону. Адже згідно канонів конституційного тлумачення кожен термін, використаний в конституційному тексті, має відповідне значення. Іншими словами, якщо конституцієдавець використовує різні терміни, відповідно і зміст цих термінів має бути відмінний.

Отже, за наведеними вище критеріями перелік органів правопорядку мають становити наступні інституції (майже всі з них виконують більше, ніж одну з перелічених вище функцій): Національна гвардія; Державна прикордонна служба; Національна поліція; Державне бюро розслідувань; Служба безпеки України; Управління державної охорони; Національне антикорупційне бюро; Бюро економічної безпеки України; органи і установи виконання покарань та слідчі ізолятори; підрозділи податкової міліції та підрозділи, які ведуть боротьбу з контрабандою в системі органів доходів і зборів.

I якщо із частиною цих органів з огляду на їх визначений законом статус все більш менш зрозуміло, адже це:

військове формування з правоохоронними функціями, що входить до системи Міністерства внутрішніх справ України (НГУ);

правоохоронний орган спещіального призначення (ДПСУ);

центральний орган виконавчої влади, який служить суспільству шляхом забезпечення охорони прав і свобод людини, протидії злочинності, підтримання публічної безпеки і порядку (НПу);

центральний орган виконавчої влади, на який покладаються завдання щодо протидії правопорушенням, що посягають на функціонування економіки держави (БЕБ);

центральний орган виконавчої влади, що реалізує державну політику у сфері виконання кримінальних покарань та пробації (у випадку із органами виконання кримінальних покарань та СІЗО); органи та підрозділи «у сфері відання» центрального органу виконавчої влади, що забезпечує формування та реалізує державну податкову і митну політику,

тобто органи, які очевидно відносяться до виконавчої влади, то з рештою все дещо складніше, адже «Для гарантування конституційного порядку, нормального функціонування держави 3 метою утвердження прав і свобод людини і забезпечення гідних умов життя Конституція України передбачає структуровану, багаторівневу, ієрархічну систему органів державної влади, які наділені відповідною компетенцією, мають свій предмет відання та владні повноваження. Здійснення державної влади на засадах її поділу на законодавчу, виконавчу та судову передбачає, що кожний орган державної влади має належати до однієї з гілок влади (законодавчої, виконавчої чи судової) або мати особливий статус, окремо визначений Основним Законом України ${ }^{24}$ ».

Так, Служба безпеки України - це державний орган спеціального призначення з правоохоронними функціями, який забезпечує державну безпеку України ${ }^{25}$, а Управління державної охорони це державний правоохоронний орган спеціального призначення, підпорядкований Президентові України та підконтрольний Верховній Раді України.

\footnotetext{
23 “Національне антикорупційне бюро України є „державним правоохоронним органом“ (органом правопорядку)». Рішення Конституційного Суду України у справі за конституційним поданням 51 народного депутата України щодо відповідності Конституції України (конституційності) Указу Президента України „Про призначення А. Ситника Директором Національного антикорупційного бюро України“ від 28.08.2020 року №9-p/2020. URL: https://ccu.gov.ua/docs/3201 (18.10.2021).

24 Рішення Конституційного Суду України у справі за конституційним поданням 46 народних депутатів України щодо відповідності Конституції України (конституційності) частини першої статті 1, пункту 2 частини першої статті 4, частини першої, абзаців першого, другого частини другої статті 5, абзаців другого, третього, четвертого, п'ятого, тридцять дев'ятого, сорокового частини третьої, частини шостої статті 8 Закону України „Про Національну комісію, що здійснює державне регулювання у сферах енергетики та комунальних послуг“ (справа про Національну комісію, що здійснює державне регулювання у сферах енергетики та комунальних послуг) від 13 червня 2019 року №5-p/2019. URL: https://ccu.gov.ua/docs/2762 (18.10.2021).
}

25 Закон України «Про Службу безпеки України» від 25 березня 1992 року №№ 2229-XII URL: https://zakon.rada.gov.ua/laws/show/2229-12\#Text (18.10.2021).

ЧАСОПИС $3 / 2021 \mid 43$ 
Нові питання виникли з початком діяльності таких органів, як Національне антикорупційне бюро та Державне бюро розслідувань. Так, останнє $\epsilon$ державним правоохоронним органом, на який покладаються завдання щодо запобігання, виявлення, припинення, розкриття та розслідування кримінальних правопорушень, віднесених до його компетенції 26.

Водночас до грудня 2019 року це був центральний орган виконавчої влади, що здійснює правоохоронну діяльність, але парламент вирішив змінити цей статус на таке утворення, як державний правоохоронний орган ${ }^{27}$.

В цьому сенсі ДБР повторює шлях НАБУ, яке, починаючи з першої редакції відповідного закону ${ }^{28}$, мало статус державного правоохоронного органу, на який покладається попередження, виявлення, припинення, розслідування та розкриття корупційних правопорушень, віднесених до його підслідності, а також запобігання вчиненню нових.

Тут на фоні достатньо обмеженого за обсягом конституційного тексту варто звернутися до позицій Конституційного Суду України. Зокрема, у Рішенні у справі про Національну комісію, що здійснює державне регулювання у сферах енергетики та комунальних послуг, Суд зазначив: «За змістом Конституції України, крім органів державної влади, обов'язкове існування і найменування яких безпосередньо визначено Основним Законом України, у системі органів державної влади можуть бути утворені:

- міністерства та інші центральні органи виконавчої влади (Кабінетом Міністрів України в межах коштів, передбачених на утримання органів виконавчої влади (пункт 91 статті 116). Водночас не можуть бути змінені назви та основне цільове призначення тих міністерств та інших центральних органів виконавчої влади, назви яких прямо чи опосередковано вказані у Конституції України (абзац восьмий пункту 3 мотивувальної частини, пункт 1 резолютивної частини Рішення Конституційного Суду України від 28 січня 2003 року № 2-рп/2003);

- суди (законом, проєкт якого вносить до Верховної Ради України Президент України після консультацій з Вищою радою правосуддя) (частина друга статті 125). При цьому не допускається створення надзвичайних та особливих судів (частина шоста статті 125);

- органи та установи для забезпечення добору суддів, прокурорів, їх професійної підготовки, оцінювання, розгляду справ щодо їх дисциплінарної відповідальності, фінансового та організаційного забезпечення судів (відповідно до закону в системі правосуддя) (частина десята статті 131).

Отже, Конституцією України передбачено систему органів державної влади, яка може коригуватися уповноваженими суб'єктами лише у конституційно визначених межах. Утворення нового органу державної влади поза цією системою і в не передбаченому Конституцією України порядку можливе лише після внесення відповідних змін до Основного Закону України» 29.

Стосовно Комісії Суд вказав, що утворення постійно діючого незалежного державного колегіального органу, який за функціональним призначенням, сферою діяльності, повноваженнями має ознаки центрального органу виконавчої влади, але не підпорядковується Кабінету Міністрів України і не належить до системи органів виконавчої влади, не узгоджується з Конституцією України.

Як бачимо, системою критеріїв, за якими Судом визначається не/конституційність державного органу, в даному випадку є:

1) функціональне призначення;

2) сфера діяльності;

26 Закон України «Про Державне бюро розслідувань» від 12 листопада 2015 року № 794-VIII URL: https://zakon.rada.gov.ua/laws/show/794-19\#Text (18.10.2021).

27 Закон України «Про внесення змін до деяких законів України щодо удосконалення діяльності Державного бюро розслідувань» від 3 грудня 2019 року №305-IX. URL: https://zakon.rada.gov.ua/laws/show/305-20\#n6 (18.10.2021).

28 Закон України «Про Національне антикорупційне бюро України» від 14 жовтня 2014 року №1698-VII. URL: https://zakon.rada.gov.ua/laws/show/1698-18/ed20141014\#Text (18.10.2021).

${ }^{29}$ Крім органів державної влади, зауважив Суд, Конституція України передбачає можливість створення відповідних органів і служб для забезпечення діяльності Верховної Ради України та Президента України. 
3) повноваження;

4) непідпорядкування Уряду;

5) неналежність до системи органів виконавчої влади.

Аналіз положень Закону № 1540 дав Суду підстави для висновку про те, що за функціональним призначенням, сферою діяльності, компетенцією Комісія має ознаки центрального органу виконавчої. Зроблено це було з огляду на концепт «формування та реалізація державної політики» у певній сфері, який використано як критерій для віднесення відповідного державного органу до виконавчої влади.

$€$ важливий нюанс - Конституція визначає повноваження Кабінету Міністрів щодо формування та реалізації політики далеко не у всіх сферах і не занадто детально, і Суд далі зазначає: «згідно з чинним законодавством формування та реалізація державної політики у певній сфері покладаються на центральні органи виконавчої влади».

Тут, використавши цю тезу для доведення факту наявності певних конституційних повноважень саме у органів виконавчої влади, Суд фактично вдався до оцінки конституційності закону з урахуванням інших актів рівня закону (навіть законодавства), а не положень Конституції, що навряд чи можна вважати бездоганним з точки зору методології обгрунтування відповідної правової позицій.

На нашу думку, слід погодитися з Судом в тому, що за умови чіткого визначення повноважень Кабінету Міністрів у певній сфері створення поза межами виконавчої влади державного органу з такими повноваженнями було би неконституційним ${ }^{30}$. Проте як бути у випадку із сферою, яка в Конституції чітко не визначена як прерогатива КМУ?

Щодо підпорядкування Комісії тому чи іншому суб'єкту (прямо чи опосередковано), то Суд зазначив: прийнявши Закон № 1540, згідно з яким Комісія $\epsilon$ постійно діючим незалежним державним колегіальним органом, членів якого призначає на посади та звільняє з посад Президент України, що не передбачено Конституцією України, Верховна Рада України вийшла за межі своїх конституційних повноважень і таким чином порушила приписи статей 6, 19, 85, 92, 106 Основного Закону України.

Також, у справі за конституційним поданням 51 народного депутата України щодо відповідності Конституції України (конституційності) Указу Президента України «Про призначення А. Ситника Директором Національного антикорупційного бюро України» ${ }^{31}$ Конституційний Суд України зазначив, що Національне антикорупційне бюро України, як орган правопорядку, фактично $\epsilon$ органом виконавчої влади, оскільки складається з центрального і територіальних управлінь, тобто поширює свої повноваження на всю територію держави, і відповідно призначення Президентом України керівника органу, який за своїми повноваженнями функціонально належить до органу виконавчої влади, призведе до розбалансування системи стримувань і противаг, порушення функціонального розподілу влад та фактичної зміни форми державного правління, передбаченої Конституцією України. Таким чином, Національне антикорупційне бюро України має ознаки органу виконавчої влади, підсумував Суд².

У іншій справі за конституційним поданням 50 народних депутатів України щодо відповідності Конституції України (конституційності) окремих положень Закону України «Про Національне антикорупційне бюро України» Суд визначив, що Конституційний припис щодо поділу влади

\footnotetext{
30 Конституційний Суд України вважає, що утворення постійно діючого незалежного державного колегіального органу, який за функціональним призначенням, сферою діяльності, повноваженнями має ознаки центрального органу виконавчої влади, але не підпорядковується Кабінету Міністрів України і не належить до системи органів виконавчої влади, не узгоджується з Конституцією України.

31 Рішення Конституційного Суду України у справі за конституційним поданням 51 народного депутата України щодо відповідності Конституції України (конституційності) Указу Президента України „Про призначення А. Ситника Директором Національного антикорупційного бюро України“ від 28.08.2020 року №9-p/2020. URL:https://ccu.gov.ua/docs/3201 (18.10.2021).

32 Ibid.
}

ЧАСОПИС 3/2021 45 
на законодавчу, виконавчу та судову як один із фундаментальних приписів щодо здійснення державної влади неодноразово розглядався Конституційним Судом України не тільки як такий, що покликаний відображати функційну визначеність кожного з державних органів (місце в системі стримувань і противаг) та забезпечувати самостійне виконання державними органами своїх функцій і повноважень, а й утверджувати права і свободи людини і громадянина та забезпечувати стабільність конституційного ладу в державі 33 .

Також, на думку Суду, з огляду на те, що Національне антикорупційне бюро України має ознаки органу виконавчої влади, а з дня ухвалення Конституційним Судом України Рішення від 28 серпня 2020 року № 9-р/2020 будь-які зміни до Закону не вносилися, оспорювані положення Закону, у яких закріплено повноваження Президента України щодо утворення цього органу правопорядку, призначення його Директора та вирішення інших питань, пов'язаних із функціонуванням Національного антикорупційного бюро України, уможливлюють втручання в компетенцію Кабінету Міністрів України.

Наводячи вичерпний перелік визначених Конституцією повноважень Президента України та оголошуючи неконституційними будь-які інші компетенції, Суд певною мірою вдається до, на нашу думку, занадто механістичного підходу. Адже будь-яке повноваження Президента встановлене не окремо від інших засад конституційного ладу, а має гармонійно з ними взаємодіяти та сприяти утвердженню конституційних цінностей, зокрема прав та свобод людини, ії гідності.

Більше того, у висновку у справі за конституційним зверненням Верховної Ради України про надання висновку щодо відповідності законопроєкту про внесення змін до статті 106 Конституції України (щодо закріплення повноважень Президента України утворювати незалежні регуляторні органи, Національне антикорупційне бюро України, призначати на посади та звільняти з посад Директора Національного антикорупційного бюро України і Директора Державного бюро розслідувань) (реєстр. № 1014) вимогам статей 157 і 158 Конституції України, Суд зазначив, що законопроєктом «передбачається розширення повноважень глави держави, яке матиме наслідком перерозподіл повноважень між Президентом України та Кабінетом Міністрів України, тому спричинить розбалансування наявної конституційної системи стримувань та противаг у механізмі реалізації державної влади в Україні та наділення Президента України не характерними для нього функціями та повноваженнями, що може призвести до поступової та завуальованої зміни балансу влади» 34.

В цьому аспекті, на наш погляд, варто погодитися із міркуваннями, викладеними у окремій думці до Рішення №11-p/2020 судді Конституційного Суду В.В. Лемака, зокрема, стосовно 1) доволі складного характеру взаємовідносин Президента України та Уряду у системі стримувань та противаг (яка значно виходить за межі тези про Кабінет Міністрів як вищий орган виконавчої влади), та 2) необхідності врахування при вирішенні питання про конституційність повноважень Президента щодо НАБУ чи іншого подібного органу конституційних приписів щодо статусу Президента як гаранта національної безпеки 35 .

Адже його першим повноваженням, визначеним статтею 106 Конституції, $\epsilon$ наступне: «забезпечує державну незалежність, національну безпеку і правонаступництво держави».

\footnotetext{
33 Рішення Конституційного Суду України у справі за конституційним поданням 50 народних депутатів України щодо відповідності Конституції України (конституційності) окремих положень Закону України „Про Національне антикорупційне бюро України“ від 16 вересня 2020 року №11-p/2020. URL: https://ccu.gov.ua/docs/3228 (18.10.2021).

34 Висновок Конституційного Суду України у справі за конституційним зверненням Верховної Ради України про надання висновку щодо відповідності законопроекту про внесення змін до статті 106 Конституції України (щодо закріплення повноважень Президента України утворювати незалежні регуляторні органи, Національне антикорупційне бюро України, призначати на посади та звільняти з посад Директора Національного антикорупційного бюро України і Директора Державного бюро розслідувань) (реєстр. № 1014) вимогам статей 157 і 158 Конституції України від 16 грудня 2019 року №7-в/2019. URL: https://ccu.gov.ua/docs/2942 (18.10.2021).

35 Окрема думка судді Конституційного Суду України Лемака В.В. стосовно Рішення Конституційного Суду України у справі за конституційним поданням 50 народних депутатів України щодо відповідності Конституції України (конституційності) окремих положень Закону України „Про Національне антикорупційне бюро України“ від 16 вересня 2020 року №11-p/2020. URL: https://ccu.gov.ua/sites/default/files/docs/11_p_2020_1.pdf (18.10.2021).
} 
3 огляду на це, у питаннях щодо прямо не передбачених Конституцією повноважень Президента у сфері функціонування того чи іншого органу правопорядку такі повноваження не можуть вважатися a priori неконституційними. 3 огляду на конкретну ситуацію в тій чи іншій сфері (в даному випадку - у сфері протидії корупції, яка однозначно набула масштабів суттєвої загрози національній безпеці ${ }^{36}$ ), не можна виключати можливість реалізації парламентом функцій, передбачених статтею 85 Конституції, зокрема, визначення засад внутрішньої і зовнішньої політики, прийняття законів, якими відповідно до статті 92 Конституції визначаються організація і діяльність органів виконавчої влади, організація і діяльність органів досудового розслідування, основи національної безпеки, зокрема через запровадження органу правопорядку та визначення засад його діяльності.

В сенсі розвитку тези про оцінку правоохоронної (чи то «правопорядкової») системи 3 огляду на конституційні цінності варто згадати рішення Конституційного Суду у справі за конституційним поданням Уповноваженого Верховної Ради України з прав людини щодо відповідності Конституції України (конституційності) частини шостої статті 216 Кримінального процесуального кодексу України ${ }^{37}$, у якому Суд зазначив, що позитивний обов'язок держави стосовно створення ефективної системи захисту життя, здоров'я та гідності людини передбачає забезпечення ефективного розслідування фактів позбавлення життя та неналежного поводження, у тому числі щодо осіб, які перебувають, зокрема, в установах виконання покарань та слідчих ізоляторах під повним контролем держави. Таке розслідування має бути, зокрема, незалежним, тобто з погляду безстороннього спостерігача не має існувати жодних сумнівів щодо інституційної або ієрархічної незалежності державного органу (його службових осіб), уповноваженого здійснювати офіційне розслідування порушень прав людини, гарантованих статтями 27, 28 Конституції України. Незалежність розслідування порушень конституційних прав людини на життя та повагу до ії гідності не може бути досягнута, якщо компетентний державний орган належить до пенітенціарної системи, а його службові особи перебувають в ієрархічній залежності від вищих посадових осіб цієї системи. Відповідно Конституційний Суд України вважає, що ієрархічне підпорядкування слідчих органів Служби вищим посадовим особам Міністерства не здатне забезпечити дотримання конституційних вимог щодо незалежності офіційного розслідування злочинів, вчинених проти осіб, які перебувають в установах виконання покарань, слідчих ізоляторах. Така ієрархічна залежність нівелює процесуальні гарантії незалежності слідчого, тобто він буде певним чином упередженим під час здійснення досудового розслідування злочинів, вчинених проти осіб, які перебувають в установах виконання покарань чи слідчих ізоляторах....

Отже, Суд оцінив статус та повноваження певного органу досудового розслідування і його місце в системі органів державної влади та дійшов висновку, що встановлена частиною шостою статті 216 Кримінального процесуального кодексу підслідність злочинів, учинених на території або в приміщеннях Державної кримінально-виконавчої служби, у взаємозв’язку з відповідним нормативно-правовим регулюванням щодо функціонування слідчих органів Служби, не здатна забезпечити здійснення ефективного розслідування порушень конституційних прав людини на життя та повагу до їі гідності, що унеможливлює виконання державою їі головного конституційного обов'язку - утвердження і забезпечення прав і свобод людини.

\footnotetext{
36 Указ Президента України «Про рішення Ради національної безпеки і оборони України від 14 вересня 2020 року «Про Стратегію національної безпеки України» від 14 вересня 2020 року №392/2020. URL: https://www.president.gov.ua/documents/3922020-35037 (18.10.2021).

37 Рішення Конституційного Суду України у справі за конституційним поданням Уповноваженого Верховної Ради України з прав людини щодо відповідності Конституції України (конституційності) частини шостої статті 216 Кримінального процесуального кодексу України від 24 квітня 2018 року №3-p/2018. URL: https://zakon.rada.gov.ua/laws/show/v003p710-18/conv (18.10.2021).
} 
На нашу думку, наведене вище дає можливість для наступних висновків:

1) Система забезпечення правопорядку є сукупністю норм, принципів, практики їх застосування та суб'єктів, що реалізують відповідні повноваження з метою гарантування неухильного дотримання приписів права та забезпечення прав людини у демократичному суспільстві. Такі питання як роль, функції та повноваження відповідних суб'єктів мають важливе значення для забезпечення конституційного ладу, зокрема в контексті утвердження верховенства права, прав людини та основоположних свобод, тому частково визначені на рівні Основного Закону.

2) Приписи Конституції стосовно правоохоронних органів, прокуратури та органів правопорядку контекстуально встановлюють загальні структурні засади функціонування національної системи органів правопорядку.

3) Прокуратура не може бути віднесена до органів правопорядку, але з огляду на здійснювані нею функції є важливою складовою системи забезпечення правопорядку. Слід погодитися з тим, що «включення нормативних положень щодо прокуратури до розділу Конституції України під назвою «Правосуддя», звичайно, аж ніяк не свідчить, що прокуратура України перетвориться на орган правосуддя» 38 .

4) Дискурс віднесення прокуратури до однієї з «гілок» влади (структурний) в практичному сенсі спричинює необхідність адаптації стереотипів щодо сутності розподілу влади до складного за своїм змістом статусу прокуратури. Натомість функціональний підхід (через визначення основних характеристик функцій, які виконуються прокуратурою) дає можливість визначити відповідний статус і враховувати його при визначенні системи стримувань та противаг.

5) Конституція дає чіткі підстави для проведення диференціації органів правопорядку та правоохоронних органів.

6) Будь-яка система органів правопорядку та правоохоронних органів має відповідати засадам конституційного ладу, гарантувати захист прав та свобод людини і запобігати узурпації влади, відповідно до букви або духу Основного закону.

7) 3 огляду на це, актуальним $\epsilon$ вироблення правових стандартів організації та функціонування органів правопорядку, під якими незалежно від назви слід розуміти державні органи (або наділені законними повноваженнями недержавні суб'єкти), що діють з метою забезпечення функціонування правової системи (або її елементів) та володіють повноваженнями з обмеження прав чи свобод особи із застосуванням (під загрозою застосування) легального примусу, в тому числі легітимного насильства. Для таких органів законодавець може встановити певні загальні критерії організації та функціонування 3 огляду на конституційні приписи щодо а) забезпечення балансу влади; б) стандартів втручання та обмеження прав людини у демократичному суспільстві.

Подальші дослідження у відповідному напрямі передбачають аналіз поточного правового регулювання у сфері розбудови системи забезпечення правопорядку з огляду на відповідність їі закладеним у Основному Законі межам та меті забезпечення прав людини і основних свобод через дотримання балансу влади у демократичному суспільстві.

\footnotetext{
38 Косюта М. Роль і місце прокуратури України в системі поділу влади. Науковий часопис Національної академії прокуратури України. 2017. № 4 (16). С. 101-113.
} 


\section{Список використаних джерел}

\section{Бібліографія:}

1. Косюта М. Роль і місце прокуратури України в системі поділу влади. Науковий часопис Національної академії прокуратури України. 2017. № 4 (16). С. 101-113.

2. Крусян А. Конституційний правопорядоку системі сучасного українського конституціоналізму. Юридичний вісник. 2009. № 1. С. 16-21.

3. Тацій В. Поняття та система правоохоронних органів: у контексті системних змін до Конституції України. Вісник Академії правових наук України. 2012. № 4. С. 3-17.

4. Opinion on the Amendments to the Constitution of Ukraine regarding the Judiciary as proposed by the Working Group of the Constitutional Commission in July 2015 endorsed by the Venice Commission at its 104th Plenary Session (Venice, 23-24 October 2015) URL: https://www.venice.coe.int/webforms/documents/?pdf=CDL$\mathrm{AD}(2015) 026$-е (18.10.2021).

5. Єсімов С.С. Реалізація конституційного оформлення правопорядку в умовах наявності конституційних ризиків. Соціально-правові студії. 2019. Випуск 3. С. 52-57.

6. Конституційне право України: підруч. / за ред. В.Ф. Погорілка. - Київ: Наукова думка. 1999. С. 596.

7. Лапкін А. Прокуратура в системі судової влади. Право України. 2015. №9. С. 164-171.

8. Шапошник А.С., Шлапко Т.В. Визначення місця прокуратури в системі органів державної влади. Правова позиція. 2020. №3. С. 71-75.

9. Подорожна Т.С. Правовий порядок: теоретико-методологічні засади конституціоналізації. Дис... доктора юрид наук. С. 48.

\section{Перелік юридичних документів:}

10. Рішення Конституційного Суду України у справі за конституційним поданням правління Пенсійного фонду України щодо офіційного тлумачення положень статті 1, частин першої, другої, третьої статті 95, частини другої статті 96, пунктів 2, 3, 6 статті 116, частини другої статті 124, частини першої статті 129 Конституції України, пункту 5 частини першої статті 4 Бюджетного кодексу України, пункту 2 частини першої статті 9 Кодексу адміністративного судочинства України в системному зв'язку з окремими положеннями Конституції України від 25 січня 2012 року № 3-рп/2012. URL: https://zakon.rada.gov.ua/laws/show/v003p710-12\#Text (18.10.2021).

11. Рішення Конституційного Суду України у справі щодо підвідомчості актів про призначення або звільнення посадових осіб від 7 травня 2002 року № 8-рп/2002. URL: https://zakon.rada.gov.ua/laws/show/v008p71002\#Text (18.10.2021).

12. Рішення Конституційного Суду України від 24 червня 1999 року № 6-рп/99 у справі про фінансування судів, метою функціонального поділу державної влади на законодавчу, виконавчу та судову є розмежування повноважень між різними органами державної влади та недопущення привласнення повноти державної влади однією з гілок влади. URL: https://zakon.rada.gov.ua/laws/show/v006p710-99\#Text (18.10.2021).

13. Рішення Конституційного Суду України від 1 квітня 2008 року № 4-pп/2008. URL: https://zakon.rada.gov.ua/laws/show/v004p710-08\#Text (18.10.2021).

14. Закон України «Про прокуратуру» від 14 жовтня 2014 року №1697-VII. URL: https://zakon.rada.gov.ua/laws/show/1697-18\#Text (18.10.2021).

15. Проект Постанови Верховної Ради України «Про стан реформування правоохоронних органів України та законодавче забезпечення їх діяльності» URL: http://w1.c1.rada.gov.ua/pls/zweb2/webproc4_1?pf3511=18865 (18.10.2021).

16. Закон України «Про державний захист працівників суду і правоохоронних органів» від 23 грудня 1993 року №3781-XII. URL: https://zakon.rada.gov.ua/laws/show/3781-12\#Text (18.10.2021).

17. Рішення Конституційного Суду України у справі за конституційним зверненням громадянина Кузьменка Віталія Борисовича щодо офіційного тлумачення положення частини третьої статті 364 Кримінального кодексу України (справа щодо застосування кваліфікуючої ознаки "працівник правоохоронного органу" до працівника державної виконавчої служби) від 18 квітня 2012 року №10-pп/2012. URL: https://zakon.rada.gov.ua/laws/show/v010p710-12\#Text (18.10.2021).

18. Закон України «Про внесення змін до Конституції України (щодо правосуддя)» від 2 червня 2016 року №1401-VIII. URL: https://zakon.rada.gov.ua/laws/show/1401-19\#n2 (18.10.2021).

19. Указ Президента України від 20 травня 2015 року №276/2015 «Про Стратегію реформування судоустрою, судочинства та суміжних правових інститутів на 2015-2020 poки». URL: https://zakon.rada.gov.ua/laws/show/276/2015\#Text (18.10/2021). 
20. Рішення Конституційного Суду України у справі за конституційним поданням 51 народного депутата України щодо відповідності Конституції України (конституційності) Указу Президента України „Про призначення А. Ситника Директором Національного антикорупційного бюро України» від 28.08.2020 року №9p/2020. URL: https://ccu.gov.ua/docs/3201 (18.10.2021).

21. Рішення Конституційного Суду України у справі за конституційним поданням 46 народних депутатів України щодо відповідності Конституції України (конституційності) частини першої статті 1, пункту 2 частини першої статті 4, частини першої, абзаців першого, другого частини другої статті 5, абзаців другого, третього, четвертого, п’ятого, тридцять дев'ятого, сорокового частини третьої, частини шостої статті 8 Закону України „Про Національну комісію, що здійснює державне регулювання у сферах енергетики та комунальних послуг» (справа про Національну комісію, що здійснює державне регулювання у сферах енергетики та комунальних послуг) від 13 червня 2019 року №5-p/2019. URL: https://ccu.gov.ua/docs/2762 (18.10.2021).

22. Закон України «Про Службу безпеки України» від 25 березня 1992 року №№ 2229-XII URL: https://zakon.rada.gov.ua/laws/show/2229-12\#Text (18.10.2021).

23. Закон України «Про Державне бюро розслідувань» від 12 листопада 2015 року № 794-VIII URL: https://zakon.rada.gov.ua/laws/show/794-19\#Text (18.10.2021).

24. Закон України «Про внесення змін до деяких законів України щодо удосконалення діяльності Державного бюро розслідувань» від 3 грудня 2019 року №305-IX. URL: https://zakon.rada.gov.ua/laws/show/305-20\#n6 (18.10.2021).

25. Закон України «Про Національне антикорупційне бюро України» від 14 жовтня 2014 року №1698-VII. URL: https://zakon.rada.gov.ua/laws/show/1698-18/ed20141014\#Text (18.10.2021).

26. Рішення Конституційного Суду України у справі за конституційним поданням 50 народних депутатів України щодо відповідності Конституції України (конституційності) окремих положень Закону України „Про Національне антикорупційне бюро України» від 16 вересня 2020 року №11-p/2020. URL: https://ccu.gov.ua/docs/3228 (18.10.2021).

27. Висновок Конституційного Суду України у справі за конституційним зверненням Верховної Ради України про надання висновку щодо відповідності законопроекту про внесення змін до статті 106 Конституції України (щодо закріплення повноважень Президента України утворювати незалежні регуляторні органи, Національне антикорупційне бюро України, призначати на посади та звільняти з посад Директора Національного антикорупційного бюро України і Директора Державного бюро розслідувань) (реєстр. № 1014) вимогам статей 157 і 158 Конституції України від 16 грудня 2019 року №7-в/2019. URL: https://ccu.gov.ua/docs/2942 (18.10.2021).

28. Окрема думка судді Конституційного Суду України Лемака В.В. стосовно Рішення Конституційного Суду України у справі за конституційним поданням 50 народних депутатів України щодо відповідності Конституції України (конституційності) окремих положень Закону України „Про Національне антикорупційне бюро України» від $16 \quad 2020$ вересня 16 은 $11-\mathrm{p} / 2020$. https://ccu.gov.ua/sites/default/files/docs/11_p_2020_1.pdf (18.10.2021).

29. Указ Президента України «Про рішення Ради національної безпеки і оборони України від 14 вересня 2020 року «Про Стратегію національної безпеки України» від 14 вересня 2020 року №392/2020. URL: https://www.president.gov.ua/documents/3922020-35037 (18.10.2021).

30. Рішення Конституційного Суду України у справі за конституційним поданням Уповноваженого Верховної Ради України з прав людини щодо відповідності Конституції України (конституційності) частини шостої статті 216 Кримінального процесуального кодексу України від 24 квітня 2018 року №3-p/2018. URL: https://zakon.rada.gov.ua/laws/show/v003p710-18/conv (18.10.2021).

\section{Bibliography:}

\section{References}

1. Kosiuta M. Rol i mistse prokuratury Ukrainy v systemi podilu vlady. Naukovyi chasopys Natsionalnoi akademii prokuratury Ukrainy. 2017. № 4 (16). S. 101-113.

2. Krusian A. Konstytutsiinyi pravoporiadok u systemi suchasnoho ukrainskoho konstytutsionalizmu. Yurydychnyi visnyk. 2009. № 1. S. 16-21.

3. Tatsii V. Poniattia ta systema pravookhoronnykh orhaniv: u konteksti systemnykh zmin do Konstytutsii Ukrainy. Visnyk Akademii pravovykh nauk Ukrainy. 2012. № 4. S. 3-17.

4. Opinion on the Amendments to the Constitution of Ukraine regarding the Judiciary as proposed by the Working Group of the Constitutional Commission in July 2015 endorsed by the Venice Commission at its 104th Plenary Session (Venice, 23-24 October 2015) URL: https://www.venice.coe.int/webforms/documents/?pdf=CDLAD(2015)026-e (18.10.2021).

5. Yesimov S.S. Realizatsiia konstytutsiinoho oformlennia pravoporiadku v umovakh naiavnosti konstytutsiinykh ryzykiv. Sotsialno-pravovi studii. 2019. Vypusk 3. S. 52-57.

6. Konstytutsiine pravo Ukrainy: pidruch. / za red. V.F. Pohorilka. - Kyiv: Naukova dumka. 1999. S. 596.

7. Lapkin A. Prokuratura v systemi sudovoi vlady. Pravo Ukrainy. 2015. №9. S. 164-171. 
8. Shaposhnyk A.S., Shlapko T.V. Vyznachennia mistsia prokuratury v systemi orhaniv derzhavnoi vlady. Pravova pozytsiia. 2020. №3. S. 71-75.

9. Podorozhna T.S. Pravovyi poriadok: teoretyko-metodolohichni zasady konstytutsionalizatsii. Dys... doktora yuryd nauk. S. 48.

\section{List of legal documents:}

10. Rishennia Konstytutsiinoho Sudu Ukrainy u spravi za konstytutsiinym podanniam pravlinnia Pensiinoho fondu Ukrainy shchodo ofitsiinoho tlumachennia polozhen statti 1, chastyn pershoi, druhoi, tretoi statti 95, chastyny druhoi statti 96, punktiv 2, 3, 6 statti 116, chastyny druhoi statti 124, chastyny pershoi statti 129 Konstytutsii Ukrainy, punktu 5 chastyny pershoi statti 4 Biudzhetnoho kodeksu Ukrainy, punktu 2 chastyny pershoi statti 9 Kodeksu administratyvnoho sudochynstva Ukrainy $\mathrm{v}$ systemnomu zviazku z okremymy polozhenniamy Konstytutsii Ukrainy vid 25 sichnia 2012 roku № 3-rp/2012. URL: https://zakon.rada.gov.ua/laws/show/v003p710-12\#Text (18.10.2021).

11. Rishennia Konstytutsiinoho Sudu Ukrainy u spravi shchodo pidvidomchosti aktiv pro pryznachennia abo zvilnennia posadovykh osib vid 7 travnia 2002 roku № 8-rp/2002. URL: https://zakon.rada.gov.ua/laws/show/v008p71002\#Text (18.10.2021).

12. Rishennia Konstytutsiinoho Sudu Ukrainy vid 24 chervnia 1999 roku № 6-rp/99 u spravi pro finansuvannia sudiv, metoiu funktsionalnoho podilu derzhavnoi vlady na zakonodavchu, vykonavchu ta sudovu ye rozmezhuvannia povnovazhen mizh riznymy orhanamy derzhavnoi vlady ta nedopushchennia pryvlasnennia povnoty derzhavnoi vlady odniieiu z hilok vlady. URL: https://zakon.rada.gov.ua/laws/show/v006p710-99\#Text (18.10.2021).

13. Rishennia Konstytutsiinoho Sudu Ukrainy vid 1 kvitnia 2008 roku № 4-rp/2008. URL: https://zakon.rada.gov.ua/laws/show/v004p710-08\#Text (18.10.2021).

14. Zakon Ukrainy «Pro prokuraturu» vid 14 zhovtnia 2014 roku №1697-VII. URL: https://zakon.rada.gov.ua/laws/show/1697-18\#Text (18.10.2021).

15. Proekt Postanovy Verkhovnoi Rady Ukrainy «Pro stan reformuvannia pravookhoronnykh orhaniv Ukrainy ta zakonodavche zabezpechennia diialnosti» URh http://w1.c1.rada.gov.ua/pls/zweb2/webproc4_1?pf3511=18865 (18.10.2021).

16. Zakon Ukrainy «Pro derzhavnyi zakhyst pratsivnykiv sudu i pravookhoronnykh orhaniv» vid 23 hrudnia 1993 roku №3781-XII. URL: https://zakon.rada.gov.ua/laws/show/3781-12\#Text (18.10.2021).

17. Rishennia Konstytutsiinoho Sudu Ukrainy u spravi za konstytutsiinym zvernenniam hromadianyna Kuzmenka Vitaliia Borysovycha shchodo ofitsiinoho tlumachennia polozhennia chastyny tretoi statti 364 Kryminalnoho kodeksu Ukrainy (sprava shchodo zastosuvannia kvalifikuiuchoi oznaky "pratsivnyk pravookhoronnoho orhanu" do pratsivnyka derzhavnoi vykonavchoi sluzhby) vid 18 kvitnia 2012 roku №10-rp/2012. URL: https://zakon.rada.gov.ua/laws/show/v010p710-12\#Text (18.10.2021).

18. Zakon Ukrainy «Pro vnesennia zmin do Konstytutsii Ukrainy (shchodo pravosuddia)» vid 2 chervnia 2016 roku №1401-VIII. URL: https://zakon.rada.gov.ua/laws/show/1401-19\#n2 (18.10.2021).

19. Ukaz Prezydenta Ukrainy vid 20 travnia 2015 roku №276/2015 «Pro Stratehiiu reformuvannia sudoustroiu, sudochynstva ta sumizhnykh pravovykh instytutiv na 2015-2020 roky». URL: https://zakon.rada.gov.ua/laws/show/276/2015\#Text (18.10/2021).

20. Rishennia Konstytutsiinoho Sudu Ukrainy u spravi za konstytutsiinym podanniam 51 narodnoho deputata Ukrainy shchodo vidpovidnosti Konstytutsii Ukrainy (konstytutsiinosti) Ukazu Prezydenta Ukrainy „Pro pryznachennia A. Sytnyka Dyrektorom Natsionalnoho antykoruptsiinoho biuro Ukrainy» vid 28.08.2020 roku №9-r/2020. URL: https://ccu.gov.ua/docs/3201 (18.10.2021).

21. Rishennia Konstytutsiinoho Sudu Ukrainy u spravi za konstytutsiinym podanniam 46 narodnykh deputativ Ukrainy shchodo vidpovidnosti Konstytutsii Ukrainy (konstytutsiinosti) chastyny pershoi statti 1, punktu 2 chastyny pershoi statti 4, chastyny pershoi, abzatsiv pershoho, druhoho chastyny druhoi statti 5, abzatsiv druhoho, tretoho, chetvertoho, piatoho, trydtsiat deviatoho, sorokovoho chastyny tretoi, chastyny shostoi statti 8 Zakonu Ukrainy „Pro Natsionalnu komisiiu, shcho zdiisniuie derzhavne rehuliuvannia u sferakh enerhetyky ta komunalnykh posluh» (sprava pro Natsionalnu komisiiu, shcho zdiisniuie derzhavne rehuliuvannia u sferakh enerhetyky ta komunalnykh posluh) vid 13 chervnia 2019 roku №5-r/2019. URL: https://ccu.gov.ua/docs/2762 (18.10.2021).

22. Zakon Ukrainy «Pro Sluzhbu bezpeky Ukrainy» vid 25 bereznia 1992 roku №№ 2229-XII URL: https://zakon.rada.gov.ua/laws/show/2229-12\#Text (18.10.2021).

23. Zakon Ukrainy «Pro Derzhavne biuro rozsliduvan» vid 12 lystopada 2015 roku № 794-VIII URL: https://zakon.rada.gov.ua/laws/show/794-19\#Text (18.10.2021).

24. Zakon Ukrainy «Pro vnesennia zmin do deiakykh zakoniv Ukrainy shchodo udoskonalennia diialnosti Derzhavnoho biuro rozsliduvan» vid 3 hrudnia 2019 roku №305-IX. URL: https://zakon.rada.gov.ua/laws/show/305-20\#n6 (18.10.2021).

25. Zakon Ukrainy «Pro Natsionalne antykoruptsiine biuro Ukrainy» vid 14 zhovtnia 2014 roku №1698-VII. URL: https://zakon.rada.gov.ua/laws/show/1698-18/ed20141014\#Text (18.10.2021).

26. Rishennia Konstytutsiinoho Sudu Ukrainy u spravi za konstytutsiinym podanniam 50 narodnykh deputativ Ukrainy shchodo vidpovidnosti Konstytutsii Ukrainy (konstytutsiinosti) okremykh polozhen Zakonu Ukrainy „Pro 
Natsionalne antykoruptsiine biuro Ukrainy» vid 16 veresnia 2020 roku №11-r/2020. URL: https://ccu.gov.ua/docs/3228 (18.10.2021).

27. Vysnovok Konstytutsiinoho Sudu Ukrainy u spravi za konstytutsiinym zvernenniam Verkhovnoi Rady Ukrainy pro nadannia vysnovku shchodo vidpovidnosti zakonoproektu pro vnesennia zmin do statti 106 Konstytutsii Ukrainy (shchodo zakriplennia povnovazhen Prezydenta Ukrainy utvoriuvaty nezalezhni rehuliatorni orhany, Natsionalne antykoruptsiine biuro Ukrainy, pryznachaty na posady ta zvilniaty $\mathrm{z}$ posad Dyrektora Natsionalnoho antykoruptsiinoho biuro Ukrainy i Dyrektora Derzhavnoho biuro rozsliduvan) (reiestr. № 1014) vymoham statei 157 i 158 Konstytutsii Ukrainy vid 16 hrudnia 2019 roku №7-v/2019. URL: https://ccu.gov.ua/docs/2942 (18.10.2021).

28. Okrema dumka suddi Konstytutsiinoho Sudu Ukrainy Lemaka V.V. stosovno Rishennia Konstytutsiinoho Sudu Ukrainy u spravi za konstytutsiinym podanniam 50 narodnykh deputativ Ukrainy shchodo vidpovidnosti Konstytutsii Ukrainy (konstytutsiinosti) okremykh polozhen Zakonu Ukrainy „Pro Natsionalne antykoruptsiine biuro Ukrainy» vid 16 veresnia 2020 roku №11-r/2020. https://ccu.gov.ua/sites/default/files/docs/11_p_2020_1.pdf (18.10.2021).

29. Ukaz Prezydenta Ukrainy «Pro rishennia Rady natsionalnoi bezpeky i oborony Ukrainy vid 14 veresnia 2020 roku «Pro Stratehiiu natsionalnoi bezpeky Ukrainy» vid 14 veresnia 2020 roku №392/2020. URL: https://www.president.gov.ua/documents/3922020-35037 (18.10.2021).

30. Rishennia Konstytutsiinoho Sudu Ukrainy u spravi za konstytutsiinym podanniam Upovnovazhenoho Verkhovnoi Rady Ukrainy z prav liudyny shchodo vidpovidnosti Konstytutsii Ukrainy (konstytutsiinosti) chastyny shostoi statti 216 Kryminalnoho protsesualnoho kodeksu Ukrainy vid 24 kvitnia 2018 roku №3-r/2018. URL: https://zakon.rada.gov.ua/laws/show/v003p710-18/conv (18.10.2021). 